\title{
Habitual physical activity in daily life correlates positively with markers for mitochondrial capacity.
}

Citation for published version (APA):

den Hoed, M., Hesselink, M. K., van Kranenburg, G. P., \& Westerterp, K. R. (2008). Habitual physical activity in daily life correlates positively with markers for mitochondrial capacity. Journal of Applied Physiology, 105(2), 561-568. https://doi.org/10.1152/japplphysiol.00091.2008

Document status and date:

Published: 01/01/2008

DOI:

10.1152/japplphysiol.00091.2008

Document Version:

Publisher's PDF, also known as Version of record

Document license:

Taverne

Please check the document version of this publication:

- A submitted manuscript is the version of the article upon submission and before peer-review. There can be important differences between the submitted version and the official published version of record.

People interested in the research are advised to contact the author for the final version of the publication, or visit the DOI to the publisher's website.

- The final author version and the galley proof are versions of the publication after peer review.

- The final published version features the final layout of the paper including the volume, issue and page numbers.

Link to publication

\footnotetext{
General rights rights.

- You may freely distribute the URL identifying the publication in the public portal. please follow below link for the End User Agreement:

www.umlib.nl/taverne-license

Take down policy

If you believe that this document breaches copyright please contact us at:

repository@maastrichtuniversity.nl

providing details and we will investigate your claim.
}

Copyright and moral rights for the publications made accessible in the public portal are retained by the authors and/or other copyright owners and it is a condition of accessing publications that users recognise and abide by the legal requirements associated with these

- Users may download and print one copy of any publication from the public portal for the purpose of private study or research.

- You may not further distribute the material or use it for any profit-making activity or commercial gain

If the publication is distributed under the terms of Article $25 \mathrm{fa}$ of the Dutch Copyright Act, indicated by the "Taverne" license above, 


\title{
Habitual physical activity in daily life correlates positively with markers for mitochondrial capacity
}

\author{
Marcel den Hoed, ${ }^{\mathbf{1}}$ Matthijs K. C. Hesselink, ${ }^{\mathbf{2}}$ Gerrit P. J. van Kranenburg, ${ }^{\mathbf{2}}$ and Klaas R. Westerterp ${ }^{\mathbf{1}}$ \\ Departments of ${ }^{1}$ Human Biology and ${ }^{2}$ Movement Sciences, Maastricht University, Maastricht, The Netherlands
}

Submitted 29 January 2008; accepted in final form 23 May 2008

\begin{abstract}
den Hoed M, Hesselink MK, van Kranenburg GP, Westerterp KR. Habitual physical activity in daily life correlates positively with markers for mitochondrial capacity. J Appl Physiol 105: 561-568, 2008. First published May 29, 2008; doi:10.1152/japplphysiol.00091.2008.— Physical exercise training is a powerful tool to maintain or improve mitochondrial density and function (mitochondrial capacity). This study aims to determine whether mitochondrial capacity is also associated with habitual physical activity in daily life $\left(\mathrm{PA}_{\mathrm{DL}}\right)$. The capacity of classic markers for mitochondrial density, i.e., the capacity of citrate synthase (CS) and succinate dehydrogenase (SDH), as well the capacity of cytochrome $c$ oxidase (COX) and $\beta$-hydroxyacyl-CoA dehydrogenase (HAD), was determined in homogenized muscle biopsy samples obtained from the vastus lateralis muscle of nonexercising healthy young (age $20 \pm 2 \mathrm{yr}$ ) subjects (31 women, 7 men). $\mathrm{PA}_{\mathrm{DL}}$ was measured during two periods of 14 days using a triaxial accelerometer for movement registration. $\mathrm{CS}, \mathrm{SDH}$, and $\mathrm{COX}$ were positively associated with $\mathrm{PA}_{\mathrm{DL}}[P<0.05, R=0.36,95 \%$ confidence interval (CI): $1.3 \cdot 10^{-4}$ to $2.2 \cdot 10^{-3} ; P<0.05, R=0.39,95 \% \mathrm{CI}$ : $1.1 \cdot 10^{-5}$ to $9.9 \cdot 10^{-5}$; and $P<0.05, R=0.33,95 \% \mathrm{CI}: 7.5 \cdot 10^{-6}$ to $3.6 \cdot 10^{-4}$, respectively], and HAD tended to correlate positively with $\mathrm{PA}_{\mathrm{DL}}\left(P=0.06, R=0.31,95 \% \mathrm{CI}:-2.2 \cdot 10^{-5}\right.$ to $\left.1.1 \cdot 10^{-3}\right)$. The population was subsequently stratified based on the intensity of the activities performed. CS was only associated with PA $\mathrm{DL}_{\mathrm{DL}}$ in subjects spending more time on high-intensity physical activity, whereas HAD was only associated with $\mathrm{PA}_{\mathrm{DL}}$ in subjects spending less time on low intensity physical activity. We are the first to report that even within the range of normal daily life activities, mitochondrial capacity is positively associated with the level of habitual physical activity in daily life. Thus an active lifestyle may help to maintain or improve mitochondrial capacity.
\end{abstract}

accelerometer; intensity; citrate synthase; succinate dehydrogenase; cyctochrome $c$ oxidase; $\beta$-hydroxyacyl-CoA dehydrogenase

IN WESTERNIZED SOCIETIES, the prevalence of Type 2 diabetes and obesity has increased significantly over the past few decades $(18,25)$. A decreased physical activity has been associated with both Type 2 diabetes $(13,17)$ and obesity $(15)$. Part of the pathophysiology related to these diseases has been attributed to a reduced mitochondrial capacity: the product of mitochondrial density and function $(2,16,22)$.

Mitochondria are vital organelles in the oxidative degradation of macronutrients to maintain cellular ATP levels. Mitochondrial aberrations, resulting in a reduced mitochondrial capacity, may therefore seriously impair normal energy and substrate metabolism. Mitochondrial aberrations have not only been reported for metabolic disorders like Type 2 diabetes and obesity but also in diseases like chronic heart failure and chronic obstructive pulmonary disease $(11,24)$.

Address for reprint requests and other correspondence: M. den Hoed, P.O. Box 616, 6200 MD Maastricht, The Netherlands (e-mail: m.denhoed@hb.unimaas.nl).
Proper mitochondrial function and maintenance of mitochondrial capacity rely on a delicate balance between mitochondrial biogenesis and degradation. While the precise mechanisms of mitochondrial biogenesis and degradation are not fully elucidated yet, it has been known for decades that one of the most potent triggers to improve or maintain mitochondrial capacity is physical exercise (9). Engagement in physical exercise programs results in increased mitochondrial biogenesis and improved mitochondrial function in healthy controls $(12,29)$ and is even capable of restoring mitochondrial capacity in diseased states like Type 2 diabetes and obesity $(21,30)$. Unfortunately, long-term adherence to strenuous exercise programs is limited (32), and life-long engagement in sports and exercise to prevent mitochondrial aberrations may be an unrealistic goal in Westernized societies. If, however, mitochondrial capacity can also be maintained by high levels of habitual physical activity in daily life $\left(\mathrm{PA}_{\mathrm{DL}}\right)$, the goal of maintaining mitochondrial capacity and preventing mitochondrial aberrations by physical activity may become feasible.

Interestingly, wide ranges in $\mathrm{PA}_{\mathrm{DL}}$ have been reported (23) with the most active people showing daily life activity levels approaching those reported for people actively engaged in endurance sports (5). While it is obvious that mitochondrial capacity is higher in trained athletes than in sedentary controls, it is not known to date whether differences also exist within the ranges of normal daily life activities. The aim of the present study was therefore to examine the association between markers of mitochondrial capacity with habitual physical activity in daily life in a young and healthy population. To this end, classic markers for muscle mitochondrial density, the capacity of citrate synthase (CS) and succinate dehydrogenase (SDH) (10), were measured along with the capacity of cytochrome $c$ oxidase or complex IV (COX) from the electron transport chain and $\beta$-hydroxyacyl-CoA dehydrogenase (HAD) from the $\beta$-oxidation $(8,28)$. $\mathrm{PA}_{\mathrm{DL}}$ was recorded using our validated noninvasive triaxial accelerometer approach (23). We hypothesized a higher mitochondrial enzymatic capacity in subjects with a higher $\mathrm{PA}_{\mathrm{DL}}$.

\section{MATERIALS AND METHODS}

\section{Subjects}

Thirty-eight healthy, nonsmoking subjects (31 women, 7 men), $20 \pm 2$ yr of age (means \pm SD), gave written informed consent to participate in this study. To minimize the effect of physical exercise training, subjects spending over $2 \mathrm{~h} / \mathrm{wk}$ on endurance sports or $5 \mathrm{~h} / \mathrm{wk}$ on sports and exercise in general were excluded from participation. Information about the purpose and protocol of the study, as well as its

The costs of publication of this article were defrayed in part by the payment of page charges. The article must therefore be hereby marked "advertisement" in accordance with 18 U.S.C. Section 1734 solely to indicate this fact. 
risks and discomfort, was provided both orally and in writing. The study conformed to the standards set by the Declaration of Helsinki, and the local Ethics Committee approved the study.

$P A_{D L}$

$\mathrm{PA}_{\mathrm{DL}}$ was measured using a triaxial accelerometer for movement registration (Tracmor IV; Philips Research, Eindhoven, The Netherlands) sensitive to a wide range of body movements. The accelerometer has been validated against doubly labeled water, the gold standard for measuring energy expenditure in daily life (23). The Tracmor registers accelerations of the trunk along the anteroposterior, mediolateral, and longitudinal axis using three uniaxial piezoelectric accelerometers [details are provided elsewhere (23)]. To ensure a valid reflection of long-term daily life activities, the accelerometer was worn for two 14-day periods under free-living conditions. Subsequently, $\mathrm{PA}_{\mathrm{DL}}$ was defined as the average of both measurement periods.

Subjects were instructed to wear the Tracmor from the moment they woke up in the morning until they went back to bed at night. To verify whether subjects lived up to this instruction, waking hours and clock times of wearing the Tracmor were noted. To make sure only representative days were included, the difference between the total time the subject was awake and the time the accelerometer was worn was not allowed to exceed $75 \mathrm{~min} /$ day. The few days during which this difference exceeded $75 \mathrm{~min}$ were excluded from the analysis. This resulted in an average of 26 representative days per subject. To ensure that subjects met the inclusion criterion concerning their participation in sports and exercise, the actual sporting hours were also recorded in the diary.

$\mathrm{PA}_{\mathrm{DL}}$ was acquired by summing the output of all three axes and is presented as megacounts per day (Mcnts/day). Using Tracmor data, the proportion of time subjects were physically active at a low, moderate, and high intensity (\%Low, \%Moderate, and \%High, respectively) was determined. The cut-off points for the intensity categories were determined in a pilot study $(n=5)$. The cut-off point for low-intensity physical activity was set by Tracmor outputs associated with walking on a treadmill at $3.5 \mathrm{~km} / \mathrm{h}$, which corresponds with $\sim 3$ metabolic equivalents (METs), i.e., three times basal metabolic rate. For moderate-intensity physical activity, a Tracmor output associated with walking on a treadmill at $5 \mathrm{~km} / \mathrm{h}$ was used, which corresponds with $\sim 4.5$ METs (1). The relevant Tracmor outputs were $16.0 \pm 3.0$ and $28.9 \pm 3.0 \mathrm{Mcnts} / \mathrm{min}$, respectively. All physical activity associated with a Tracmor output higher than the latter cut-off point was considered high-intensity physical activity. The proportion of time per intensity category was calculated as the sum of all minutes per intensity category divided by the total duration of the measurement, i.e., 28 days minus the number of excluded days.

Using linear regression analysis in a population similar to the present study with respect to $\mathrm{PA}_{\mathrm{DL}}$, body composition, and age, Plasqui et al. (23) were able to predict physical activity level (PAL), i.e., the factor by which average daily metabolic rate exceeds basal metabolic rate, with an explained variation of $70 \%$ using only megacounts per day. Whereas the MET score represents the factor by which energy expenditure exceeds basal metabolic rate for a certain predefined physical activity, PAL represents the factor by which energy expenditure exceeds basal metabolic rate during $24 \mathrm{~h}$. For a proper reflection of 24-h daily life energy expenditure under free-living conditions, PAL thus provides a more valid reflection than MET scores, which in turn provide a more valid reflection of energy expenditure when considering predefined physical activities. The regression equation developed by Plasqui et al. was used in the present study to estimate PAL.

\section{Muscle Biopsies}

A muscle biopsy was obtained after an overnight fast with subjects refraining from strenuous physical activity for $24 \mathrm{~h}$ before the collec- tion. The biopsy was obtained from the vastus lateralis muscle under local anesthesia (2\% xylocaine) using a Bergström needle with suction (3). After muscle samples were freed from blood, visible fat, and connective tissue, they were immediately frozen in liquid nitrogen and stored at $-80^{\circ} \mathrm{C}$ until analyzed.

\section{Measurements of Enzyme Activities}

SET buffer was prepared by dissolving $8.557 \mathrm{~g}$ sucrose $(250 \mathrm{mM})$, $0.211 \mathrm{~g}$ Tris $(10 \mathrm{mM})$, and $0.0744 \mathrm{~g}$ EDTA $(2 \mathrm{mM})$ in $80 \mathrm{ml}$ distilled water. $\mathrm{pH}$ was adjusted to 7.4 , and distilled water was added to a final volume of $100 \mathrm{ml}$. Muscle samples were weighed (mean $\pm \mathrm{SD}$ : $39.0 \pm 18.8 \mathrm{mg}$ ) and homogenized in $1 \mathrm{ml}$ of SET buffer using a Polytron homogenizer (Polytron-Aggregate; Kinematica, Littau, Lucerne, Switzerland). Homogenates were frozen and thawed two additional times using liquid nitrogen to break mitochondrial membranes and were subsequently stored at $-80^{\circ} \mathrm{C}$ until analyzed.

On analysis, muscle homogenates were centrifuged at 13,000 $g$ for $2 \mathrm{~min}$. Supernatant was used for analysis. Absorbance changes for all enzyme assays were measured in a COBAS-FARA semiautomatic analyzer (COBAS-FARA; Roche, Basel, Switzerland). The molar extinction coefficients used were $13,600 \mathrm{l} \cdot \mathrm{mol}^{-1} \cdot \mathrm{cm}^{-1}$ for coenzyme A-DTNB at $412 \mathrm{~nm}$ for CS, $21,000 \mathrm{l} \cdot \mathrm{mol}^{-1} \cdot \mathrm{cm}^{-1}$ for dichlorophenol indophenol (DCPIP) at $600 \mathrm{~nm}$ for SDH, $15,3001 \cdot \mathrm{mol}^{-1} \cdot \mathrm{cm}^{-1}$ for reduced cytochrome $c$ at $550 \mathrm{~nm}$ for $\mathrm{COX}$, and $63,0001 \cdot \mathrm{mol}^{-1} \cdot \mathrm{cm}^{-1}$ for nicotinamide-adenine dinucleotide (NADH) at $340 \mathrm{~nm}$ for HAD. Enzyme capacities were expressed as micromoles per minute per gram wet weight. The compositions of the assay solutions were as follows.

1) CS. For reagent 1, $1.21 \mathrm{~g}$ Tris (100 mM), $4 \mathrm{mg}$ DTNB (100 $\mu \mathrm{M})$, and $4.2 \mathrm{mg}$ acetyl $\mathrm{CoA}(50 \mu \mathrm{M})$ were dissolved in $80 \mathrm{ml}$ distilled water, $\mathrm{pH}$ was adjusted to 8.0 , and distilled water was added to a total volume of $100 \mathrm{ml}$. For reagent 2 (starting reagent), $3.3 \mathrm{mg}$ oxaloacetate was dissolved in $1 \mathrm{ml}$ distilled water.

2) $\mathrm{SDH}$. For $\mathrm{NaP}_{\mathrm{i}} 50 \mathrm{mM}$ buffer, $0.890 \mathrm{~g} \mathrm{Na}_{2} \mathrm{HPO}_{4} \cdot 2 \mathrm{H}_{2} \mathrm{O}(50$ $\mathrm{mM})(A)$ and $0.780 \mathrm{~g} \mathrm{NaH} \mathrm{PO}_{4} \cdot 2 \mathrm{H}_{2} \mathrm{O}(50 \mathrm{mM})(B)$ were both dissolved in $100 \mathrm{ml}$ distilled water. Subsequently, $B$ was added to $A$ until the $\mathrm{pH}$ was 7.4. For reaction reagent, $6.5 \mathrm{mg} \mathrm{KCN} \mathrm{(1} \mathrm{mM),} 1.7$ $\mathrm{mg}$ 2,6-DCPIP (0.06 mM), $162 \mathrm{mg}$ sodium succinate $(10 \mathrm{mM})$, and 50 $\mathrm{mg}$ albumin were dissolved in $100 \mathrm{ml} \mathrm{KP_{i }}$ buffer.

3) $\mathrm{COX}$. For $\mathrm{KP}_{\mathrm{i}} 50 \mathrm{mM}$ buffer, $0.684 \mathrm{~g} \mathrm{KH}_{2} \mathrm{PO}_{4}(50 \mathrm{mM})$ and $1.14 \mathrm{~g} \mathrm{~K}_{2} \mathrm{HPO}_{4}(50 \mathrm{mM})$ were both dissolved in $100 \mathrm{ml}$ distilled water. Subsequently, both solutions were mixed, and $\mathrm{pH}$ was adjusted to 7.4 using $\mathrm{KOH}$. For reduced cytochrome $c$ solution, $17.6 \mathrm{mg}$

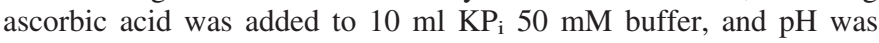
adjusted to 7.4 using $\mathrm{NaOH}(1 \mathrm{M})$. One-hundred microliters of this ascorbic acid solution and $25 \mathrm{mg}$ cytochrome $c$ were mixed. This mixture was incubated at $25^{\circ} \mathrm{C}$ for $5 \mathrm{~min}$ before $900 \mu \mathrm{K} \mathrm{KP_{i }} 50 \mathrm{mM}$ buffer was added. This solution was kept on ice until analyzed. For $\mathrm{MgCl}_{2}$ solution, $566 \mathrm{mg} \mathrm{MgCl} 2$ was dissolved in $10 \mathrm{ml}$ distilled water (final volume). For reaction reagent, $10 \mathrm{ml} \mathrm{KP}$ i $50 \mathrm{mM}$ buffer, $200 \mu \mathrm{l}$ $\mathrm{MgCl}_{2}$ solution, and $400 \mu \mathrm{l}$ reduced cytochrome $c$ solution were mixed. Fifty microliters supernatant was mixed with $200 \mu \mathrm{K} \mathrm{KP}_{\mathrm{i}} 50$ $\mathrm{mM}$ buffer, which was kept on ice for $10 \mathrm{~min}$ before analysis.

4) $H A D$. For buffer, $3.3 \mathrm{~g}$ tetrasodiumpyrophosphate $(100 \mathrm{mM})$ was dissolved in $80 \mathrm{ml}$ distilled water, $\mathrm{pH}$ was adjusted to 7.3 , and distilled water was added to a total volume of $100 \mathrm{ml}$. For NADH solution, $8.0 \mathrm{mg}$ NADH was dissolved in $1 \mathrm{ml}$ distilled water. For reagent $1,10 \mathrm{ml}$ buffer and $200 \mu \mathrm{l} \mathrm{NADH}$ solution were mixed. For reagent 2 (starting reagent), $5.0 \mathrm{mg}$ acetoacetyl-CoA was dissolved in $2.5 \mathrm{ml}$ distilled water.

All analyses for a given enzyme were performed simultaneously at $37^{\circ} \mathrm{C}$. Enzyme capacities were measured twice on the same homogenate for each subject. Intra-assay coefficients of variation were $2.0 \%$ for $\mathrm{CS}, 2.1 \%$ for $\mathrm{SDH}, 5.0 \%$ for $\mathrm{COX}$ and $1.7 \%$ for HAD, indicating that the capacity of mitochondrial enzymes was reproducibly determined. 


\section{Body Composition}

Body mass and height were measured in the morning after an overnight fast (ID 1 Plus, Mettler Toledo, Giessen, Germany; Mod. 220, SECA, Hamburg, Germany). Body volume was determined using the underwater weighing technique while correcting for residual lung volume using the helium dilution technique (Volugraph VG 2000; Mijnhardt, Bunnik, The Netherlands). Total body water was determined overnight using the deuterium dilution technique (34). Percent body fat was subsequently calculated using Siri's threecompartment model (27).

\section{Statistics}

Differences in $\mathrm{PA}_{\mathrm{DL}}$, the capacity of mitochondrial enzymes, and body composition between men and women were tested using Student's $t$-tests for unpaired samples. Simple linear regression was used to test the association between $\mathrm{CS}, \mathrm{SDH}, \mathrm{COX}$, and HAD on the one hand and $\mathrm{PA}_{\mathrm{DL}}$ on the other hand. Multiple linear regression analyses were used to test the interaction between sex and $\mathrm{PA}_{\mathrm{DL}}$ for the capacity of the mitochondrial enzymes. Backward multiple linear regression analyses were used to correct the associations between the capacity of mitochondrial enzymes and $\mathrm{PA}_{\mathrm{DL}}$ for sex, age, and body mass index (BMI). On log transformation, the association between $\mathrm{PA}_{\mathrm{DL}}$ and the capacity of the mitochondrial enzymes with \%Low, $\%$ Moderate, and \%High was determined using simple linear regression analyses.

Statistical analyses were carried out using the Statistical Package for Social Sciences (SPSS) version 11 for Macintosh OS X (SPSS; Chicago, IL). Data are expressed as means \pm SD. $P$ values $<0.05$ were considered statistically significant; $95 \%$ confidence intervals $(95 \% \mathrm{CI})$ are provided.

\section{RESULTS}

$\mathrm{PA}_{\mathrm{DL}}$ was similar between men and women (Table 1). The proportion of time subjects were physically active at a low, moderate, and high intensity was also comparable between sexes, although \%High was significantly higher in men: 18

Table 1. Results

\begin{tabular}{|c|c|c|}
\hline & Men & Women \\
\hline$n$ & 7 & 31 \\
\hline Age, yr & $20 \pm 2$ & $20 \pm 2$ \\
\hline Body mass, $\mathrm{kg}$ & $79.3 \pm 14.1$ & $63.1 \pm 8.2 \dagger$ \\
\hline Height, $\mathrm{m}$ & $1.84 \pm 0.06$ & $1.69 \pm 0.06$ \\
\hline BMI, $\mathrm{kg} / \mathrm{m}^{2}$ & $23.2 \pm 3.0$ & $22.0 \pm 2.5$ \\
\hline$\% \mathrm{BF}$ & $15.9 \pm 5.8$ & $26.7 \pm 4.6$ \\
\hline $\mathrm{PA}_{\mathrm{DL}}$, Mcnts/day & $4,128 \pm 636$ & $3,704 \pm 675$ \\
\hline$\%$ Low, $\min / 24 \mathrm{~h}$ & $1,390 \pm 15$ & $1,401 \pm 15$ \\
\hline$\%$ Moderate, $\min / 24 \mathrm{~h}$ & $33 \pm 8$ & $30 \pm 13$ \\
\hline$\%$ High, $\min / 24 \mathrm{~h}$ & $18 \pm 11$ & $9 \pm 6^{*}$ \\
\hline PAL & $1.88 \pm 0.10$ & $1.80 \pm 0.11$ \\
\hline $\mathrm{CS}, \mu \mathrm{mol} \cdot \min ^{-1} \cdot \mathrm{g}^{-1}$ & $9.30 \pm 1.75$ & $8.05 \pm 2.33$ \\
\hline $\mathrm{SDH}, \mu \mathrm{mol} \cdot \mathrm{min}^{-1} \cdot \mathrm{g}^{-1}$ & $0.70 \pm 0.11$ & $0.73 \pm 0.10$ \\
\hline $\mathrm{COX}, \mu \mathrm{mol} \cdot \min ^{-1} \cdot \mathrm{g}^{-1}$ & $0.67 \pm 0.30$ & $0.77 \pm 0.39$ \\
\hline $\mathrm{HAD}, \mu \mathrm{mol} \cdot \min ^{-1} \cdot \mathrm{g}^{-1}$ & $5.10 \pm 1.47$ & $4.79 \pm 1.20$ \\
\hline
\end{tabular}

Data are means \pm SD. BMI, body mass index; \%BF, percent body fat; $\mathrm{PA}_{\mathrm{DL}}$, habitual physical activity in daily life as measured using a triaxial accelerometer during 2 periods of 2 wk; Mcnts, megacounts; \%Low, \%Moderate, and \%High, proportion of time subjects were physically activity at a low, moderate and high intensity, respectively; PAL, physical activity level, i.e., the factor by which total energy expenditure exceeds resting energy expenditure; $\mathrm{CS}, \mathrm{SDH}, \mathrm{COX}$ and HAD, capacity of citrate synthase, succinate dehydrogenase, cytochrome $c$ oxidase, and $\beta$-hydroxyacyl-CoA dehydrogenase, expressed as $\mu \mathrm{mol}$ substrate converted per min per $\mathrm{g}$ wet muscle weight. Significant sex difference: ${ }^{*} P<0.01, \dagger P<0.001$. $\mathrm{min} /$ day vs. $9 \mathrm{~min} /$ day in women $(P<0.01,95 \% \mathrm{CI}: 2.4$ to 14.3). No significant differences between men and women were found for $\mathrm{CS}, \mathrm{SDH}, \mathrm{COX}$, or HAD, which confirms the findings of previous studies $(14,26,29)$. Furthermore, no interaction was observed between sex and $\mathrm{PA}_{\mathrm{DL}}$ for the capacity of the mitochondrial enzymes. Hence, both sexes were combined for further analyses.

\section{Capacity of Mitochondrial Enzymes and Physical Activity in Daily Life}

Applying the regression equation developed by Plasqui et al. (23) to the present population showed that the physical activity level, PAL, ranged from 1.62 to 2.04. Positive associations were observed between $\mathrm{CS}, \mathrm{SDH}$, and $\mathrm{COX}$ with $\mathrm{PA}_{\mathrm{DL}}(P<$ $0.05, R=0.36,95 \% \mathrm{CI}: 1.3 \cdot 10^{-4}$ to $2.2 \cdot 10^{-3} ; P<0.05, R=$ $0.39,95 \% \mathrm{CI}: 1.1 \cdot 10^{-5}$ to $9.9 \cdot 10^{-5}$; and $P<0.05, R=0.33$, $95 \% \mathrm{CI}: 7.5 \cdot 10^{-6}$ to $3.6 \cdot 10^{-4}$, respectively). HAD tended to correlate positively with $\mathrm{PA}_{\mathrm{DL}}(P=0.06, R=0.31,95 \% \mathrm{CI}$ : $-2.2 \cdot 10^{-5}$ to $1.1 \cdot 10^{-3}$ ) (Fig. 1$)$. These associations remained when sex, age, and/or BMI were taken into account.

$\mathrm{PA}_{\mathrm{DL}}$ was positively associated with $\%$ Moderate and $\% \mathrm{High}$ $\left(P<0.001, R=0.74,95 \% \mathrm{CI}: 3.3 \cdot 10^{-1}\right.$ to $6.3 \cdot 10^{-1}$; and $P<$ $0.001, R=0.74,95 \% \mathrm{CI}: 1.4 \cdot 10^{-1}$ to $2.6 \cdot 10^{-1}$, respectively) and negatively with \%Low $(P<0.001, R=0.86,95 \% \mathrm{CI}$ : -20.4 to -13.7$)$. CS and HAD tended to correlate positively with \%High $\left(P=0.06, R=0.31,95 \% \mathrm{CI}:-4.5 \cdot 10^{-3}\right.$ to $2.6 \cdot 10^{-1}$; and $P=0.07, R=0.30,95 \% \mathrm{CI}:-1.0 \cdot 10^{-2}$ to $2.5 \cdot 10^{-1}$, respectively). COX and $\mathrm{SDH}$ on the other hand correlated positively with \%Moderate $(P<0.05, R=0.37$, 95\% CI: $1.1 \cdot 10^{-1}$ to 1.3 ; and $P<0.05, R=0.37,95 \% \mathrm{CI}$ : $2.6 \cdot 10^{-2}$ to $3.3 \cdot 10^{-1}$, respectively). To examine if the associations between markers for mitochondrial capacity and $\mathrm{PA}_{\mathrm{DL}}$ were influenced by the intensity of the activities performed, the population was subsequently stratified based on the intensity of the activities measured.

\section{Capacity of Mitochondrial Enzymes and Physical Activity in Daily Life Stratified Based on the Intensity of Physical Activity}

Stratification of the population based on the median of $\%$ High resulted in a cut-off point of $8 \mathrm{~min} /$ day. Within the population stratified based on \%High, CS was only associated with $\mathrm{PA}_{\mathrm{DL}}$ in the subgroup spending more than $8 \mathrm{~min} /$ day on high-intensity physical activity $\left(P<0.05,95 \% \mathrm{CI}: 7.5 \cdot 10^{-5}\right.$ to $\left.2.9 \cdot 10^{-3}\right)$. SDH also correlated positively with $\mathrm{PA}_{\mathrm{DL}}$ in the subgroup spending more than $8 \mathrm{~min} /$ day on high-intensity physical activity but tended to correlate positively with $\mathrm{PA}_{\mathrm{DL}}$ in the subgroup spending less time on high-intensity physical activity as well $\left(P<0.01,95 \% \mathrm{CI}: 2.4 \cdot 10^{-5}\right.$ to $1.2 \cdot 10^{-4}$; and $P=0.07,95 \% \mathrm{CI}:-1.1 \cdot 10^{-5}$ to $2.1 \cdot 10^{-4}$, respectively). $\mathrm{COX}$ tended to correlate positively with $\mathrm{PA}_{\mathrm{DL}}$ in both the subgroup spending more and less than $8 \mathrm{~min} /$ day on highintensity physical activity $\left(P=0.06,95 \% \mathrm{CI}:-1.3 \cdot 10^{-5}\right.$ to $4.5 \cdot 10^{-4}$; and $P=0.09,95 \% \mathrm{CI}:-7.2 \cdot 10^{-5}$ to $7.7 \cdot 10^{-4}$, respectively), and $\mathrm{HAD}$ was not associated with $\mathrm{PA}_{\mathrm{DL}}$ in either the subgroup spending more or less time on high-intensity physical activity (Fig. 2).

Stratification of the population based on the median of $\%$ Moderate resulted in a cut-off point of $29 \mathrm{~min} /$ day. Within the population stratified based on \%Moderate, no associations 
Fig. 1. Mitochondrial capacity as a function of habitual physical activity in daily life. Capacity of citrate synthase (CS; $A$ ), succinate dehydrogenase ( $\mathrm{SDH} ; B$ ), cytochrome $c$ oxidase (COX; $C$ ), and $\beta$-hydroxyacyl-CoA dehydrogenase $(\mathrm{HAD} ; D)$ as a function of habitual physical activity in daily life ( $\left.\mathrm{PA}_{\mathrm{DL}}\right)$, measured using a triaxial accelerometer for movement registration, for men and women combined, is shown. $A, B$, and $C: P<0.05$. $D: P=0.06$. Mcnts, megacounts.
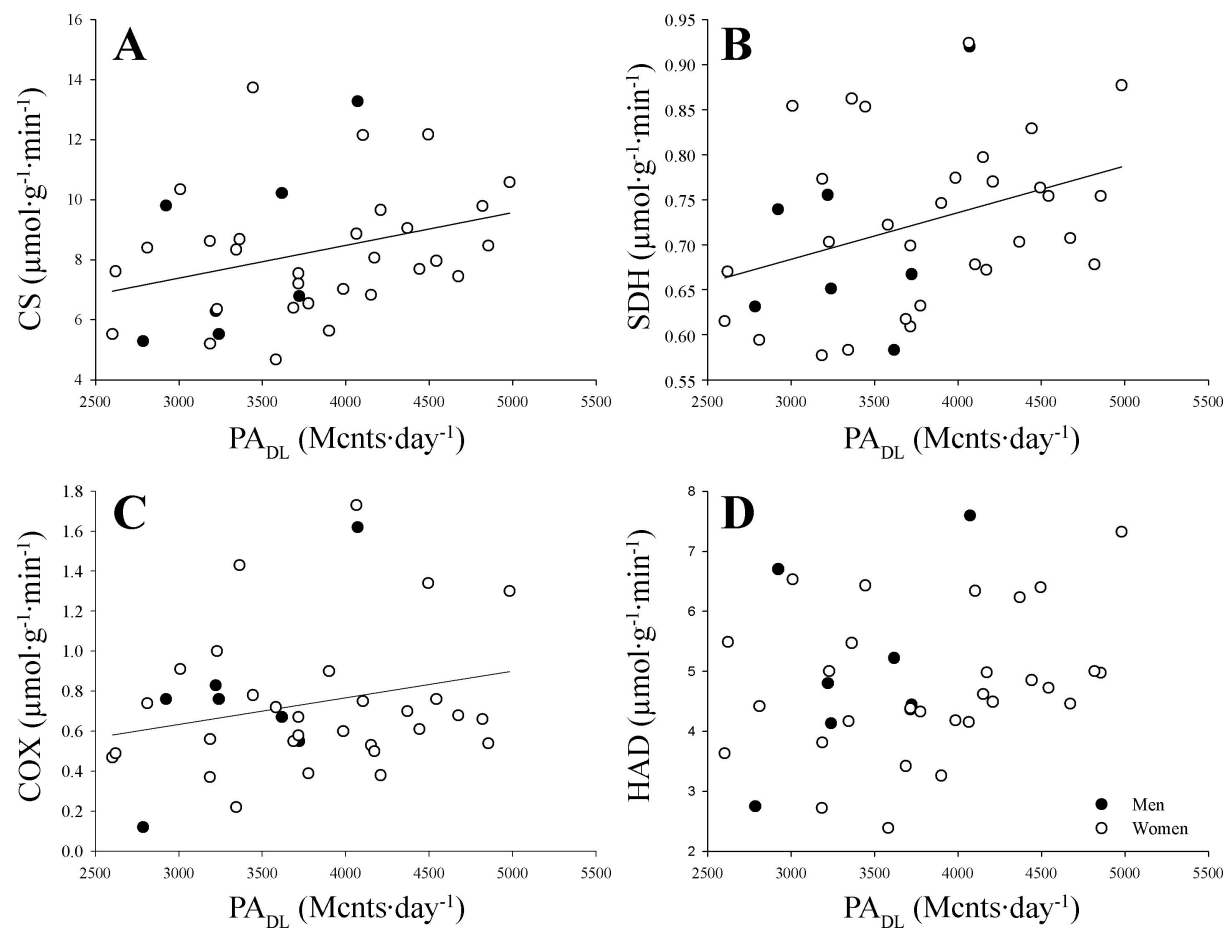

were observed between markers for mitochondrial capacity and $\mathrm{PA}_{\mathrm{DL}}$ in either the subgroup spending more or less time on moderate-intensity physical activity.

Stratification of the population based on the median of $\%$ Moderate and \%High combined resulted in a cut-off point of $39 \mathrm{~min} /$ day. Within the population stratified based on the proportion of moderate- and high-intensity physical activity, $\mathrm{CS}$ and HAD were only positively associated with $\mathrm{PA}_{\mathrm{DL}}$ in the subgroup spending more time on moderate- and high-intensity physical activity $\left(P<0.05,95 \%\right.$ CI: $1.9 \cdot 10^{-4}$ to $4.1 \cdot 10^{-3}$; and $P<0.01,95 \%$ CI: $5.7 \cdot 10^{-4}$ to $2.6 \cdot 10^{-3}$, respectively). $\mathrm{SDH}$ and COX were positively associated with $\mathrm{PA}_{\mathrm{DL}}$ in both the subgroup spending more and less time on moderate- and high-intensity physical activity $\left(P<0.01,95 \% \mathrm{CI}: 3.8 \cdot 10^{-5}\right.$ to $1.7 \cdot 10^{-4}$ and $P<0.05,95 \% \mathrm{CI}: 1.1 \cdot 10^{-5}$ to $2.4 \cdot 10^{-4}$ for SDH; $P<0.05$, $95 \%$ CI: $2.2 \cdot 10^{-5}$ to $6.0 \cdot 10^{-4}$ and $P<0.05$, 95\% CI: $8.4 \cdot 10^{-5}$ to $9.6 \cdot 10^{-4}$ for COX) (Fig. 3).

\section{DISCUSSION}

We are the first to show that within the range of normal daily life activities, mitochondrial capacity measured as the capacity of CS, SDH, and COX correlated positively with $\mathrm{PA}_{\mathrm{DL}}$, and HAD capacity tended $(P=0.06)$ to correlate positively with $\mathrm{PA} \mathrm{DL}_{\mathrm{DL}}$. These associations were independent of sex, age, and BMI.

PAL can vary from 1.2 to 2.5 in sustainable lifestyles with 1.2 observed in bed-bound subjects that are still eating and 2.5 being defined as a highly physically active lifestyle (4). In extreme situations, such as the Tour the France cycling competition, PAL has been shown to increase up to 5 (33). The range in PAL obtained in the present study was 1.6 to 2.0 , so lower than the 2.5 observed for highly physically active lifestyles. A PAL of 1.6 is regarded to reflect a sedentary lifestyle (4), and a PAL of 2.1 represents a physically active lifestyle (31). Thus our subjects covered the range of normal daily life activity levels as reflected in PAL but were not highly physically active.

The normal range of daily life activities in the present population is confirmed by the proportion of time that subjects on average spent on moderate- and high-intensity physical activity, i.e., 30 and $11 \mathrm{~min}$, respectively. These proportions are close to those recently reported in other studies that used accelerometry in healthy young adults $(7,35)$. McClain et al. (20), on the other hand, recruited regular endurance runners and although \%Moderate was similar in their study $(27 \mathrm{~min} /$ day), \%High was more pronounced (48 min/day) compared with the present population. This suggests that although physically active subjects were evidently recruited in the present study, the proportion of high-intensity physical activity was much lower than previously observed for people actively engaged in endurance sports.

$\mathrm{PA}_{\mathrm{DL}}$ correlated positively with \%Moderate and with \%High. Furthermore, positive associations were observed between markers for mitochondrial capacity and both \% Moderate and $\%$ High. This suggests that the intensity of the activities performed may have affected the association between our markers for mitochondrial capacity and PADL. Indeed, stratification of the population based on the intensity of the activities performed made the association between markers for mitochondrial capacity and $\mathrm{PA}_{\mathrm{DL}}$ more prominent. Evidently, as a classic marker for mitochondrial density, CS was only associated with $\mathrm{PA}_{\mathrm{DL}}$ in the subgroup spending more than $8 \mathrm{~min} / \mathrm{day}$ on high-intensity physical activity. Importantly, this suggests that although $\mathrm{CS}$ was associated with $\mathrm{PA}_{\mathrm{DL}}$ in the entire population, there may be a lower limit for the time spent on high-intensity physical activity that should be met for the association to become apparent. Since $\mathrm{PA}_{\mathrm{DL}}$ and \%High were both significantly higher in the subgroup spending more time on high-intensity physical activity (data not shown), the association found could theoretically also result from an increased 

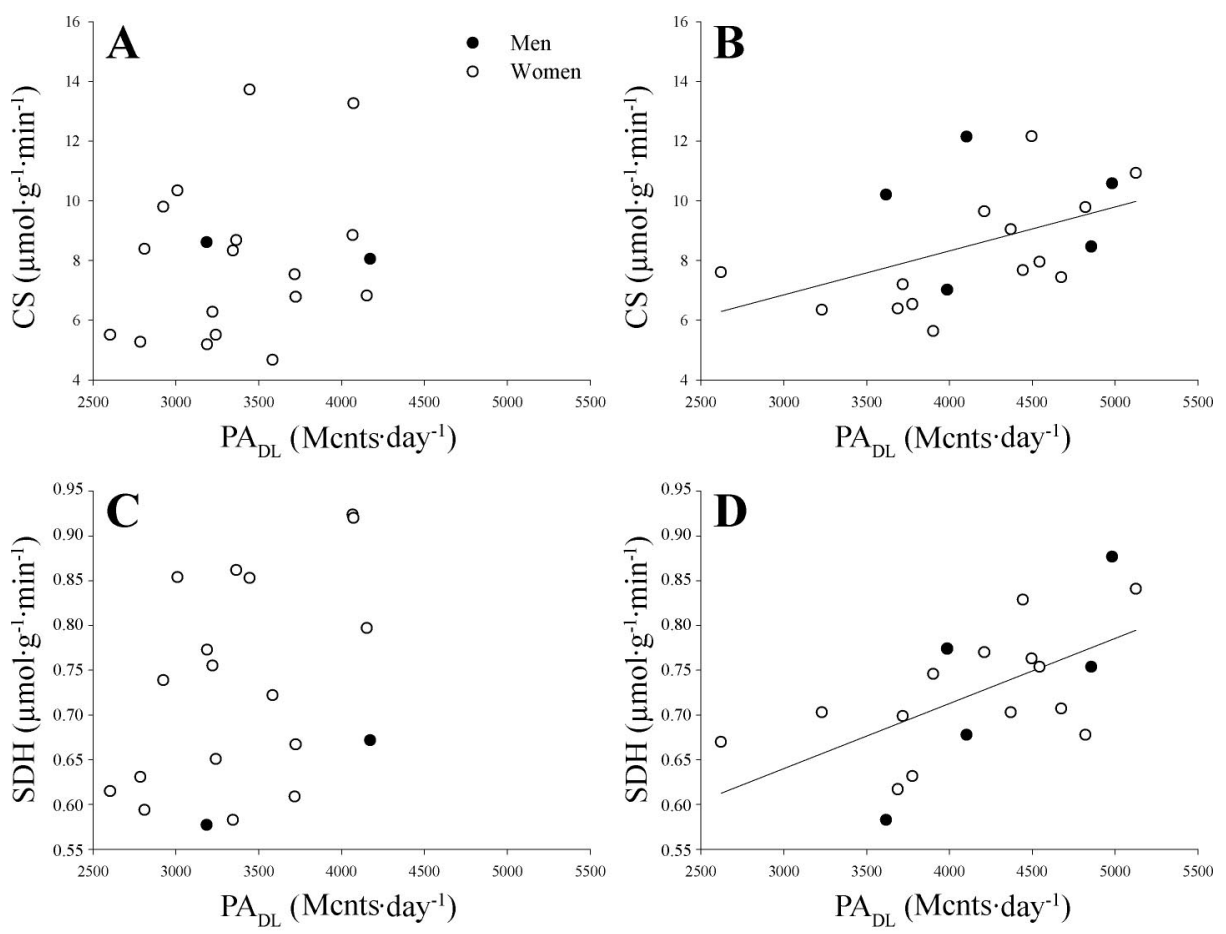

Fig. 2. Capacity of CS ( $A$ and $B), \operatorname{SDH}(C$ and $D), \operatorname{COX}(E$ and $F)$, and $\operatorname{HAD}(G$ and $H)$ as a function of $\mathrm{PA} \mathrm{DL}_{\mathrm{DL}}$, measured using a triaxial accelerometer for movement registration, stratified based on the proportion of time subjects were physically active at a high intensity. $A, C, E$, and $G$ show the association for subjects who spent
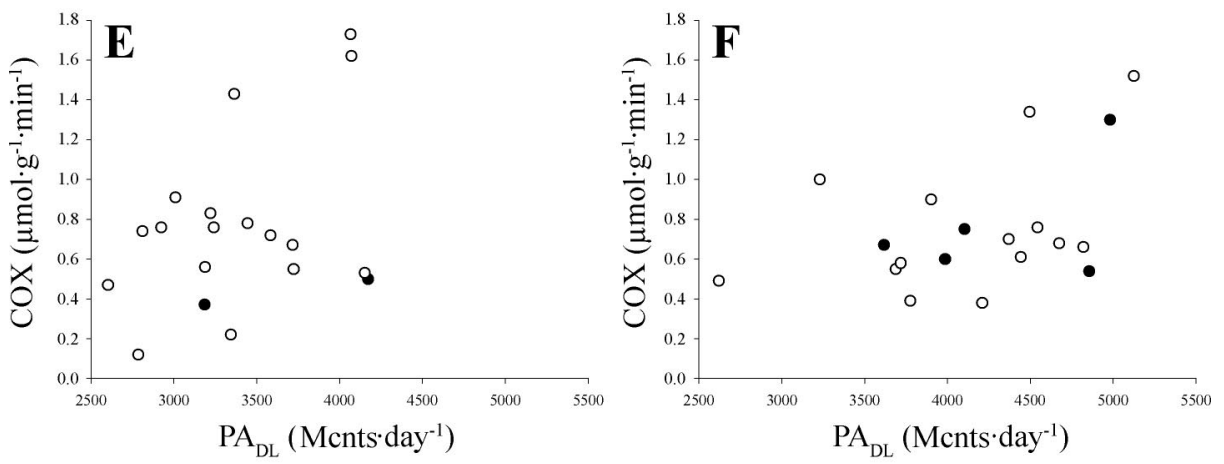
2-8 $\mathrm{min} /$ day on high-intensity physical activity, and $B, D, F$, and $H$ for subjects who spent $9-34$ min/day on high-intensity physical activity. $B$ : $P<0.05 . C: P=0.07 . D: P<0.01 . E: P=$ 0.09. $F: P=0.06$.
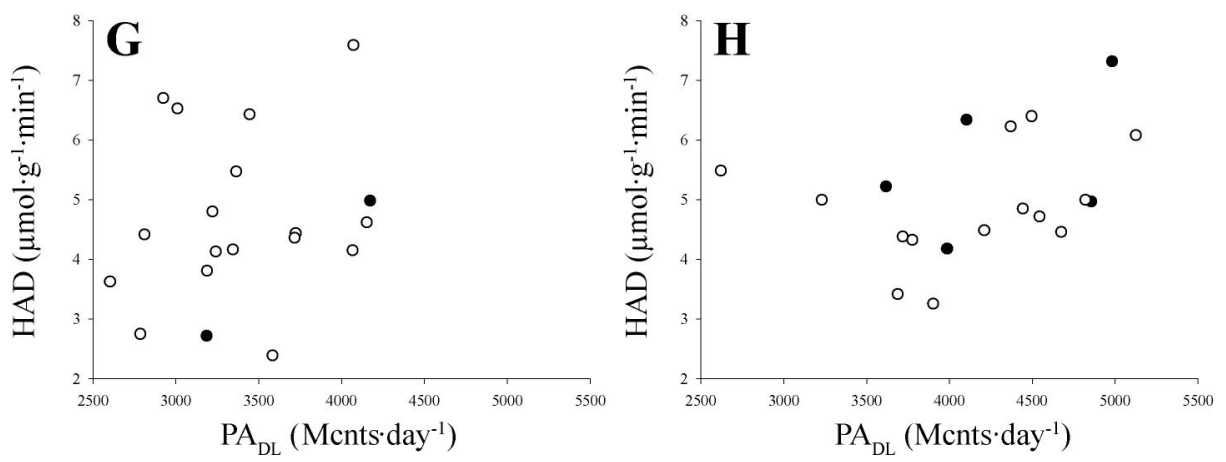

$\mathrm{PA}_{\mathrm{DL}}$. However, stratification of the population based on \% Moderate did not reveal an association between CS or any other marker for mitochondrial capacity and $\mathrm{PA} \mathrm{DL}_{\mathrm{DL}}$ in either the subgroup spending more or less than $29 \mathrm{~min} / \mathrm{day}$ on moderateintensity physical activity. Therefore, we conclude that highintensity physical activity may be a prerequisite for a positive association between CS and $\mathrm{PA}_{\mathrm{DL}}$.

Within the population stratified based on the median of the time spent on moderate- and high-intensity physical activity combined, HAD showed a positive association with $\mathrm{PA}_{\mathrm{DL}}$ in subjects spending more but not in subjects spending less than $39 \mathrm{~min} /$ day on moderate- and high-intensity physical activity. On first thought, this seems inconsistent since HAD was not associated with $\mathrm{PA}_{\mathrm{DL}}$ within the population stratified based on $\%$ Moderate or \%High separately. However, the proportion of moderate- and high-intensity physical activity combined is by definition the inverse of the proportion of low-intensity physical activity. In other words, the association observed between $\mathrm{HAD}$ and $\mathrm{PA}_{\mathrm{DL}}$ in subjects spending more than $39 \mathrm{~min} /$ day on moderate- and high-intensity physical activity probably results 
Fig. 3. Capacity of CS $(A$ and $B), \operatorname{SDH}(C$ and $D), \operatorname{COX}(E$ and $F)$, and $\operatorname{HAD}(G$ and $H)$ as a function of $\mathrm{PA} \mathrm{DL}_{\mathrm{DL}}$, measured using a triaxial accelerometer for movement registration, stratified based on the proportion of time subjects were physically active at a moderate and high intensity. $A, C, E$, and $G$ show the association for subjects who spent $18-39 \mathrm{~min} /$ day on moderateand high-intensity physical activity, and $B, D, F$, and $H$ for subjects who spent 39-72 min/day on moderate- and high-intensity physical activity. $B$, $C$, E, and $F: P<0.05 . D$ and $H: P<0.01$.
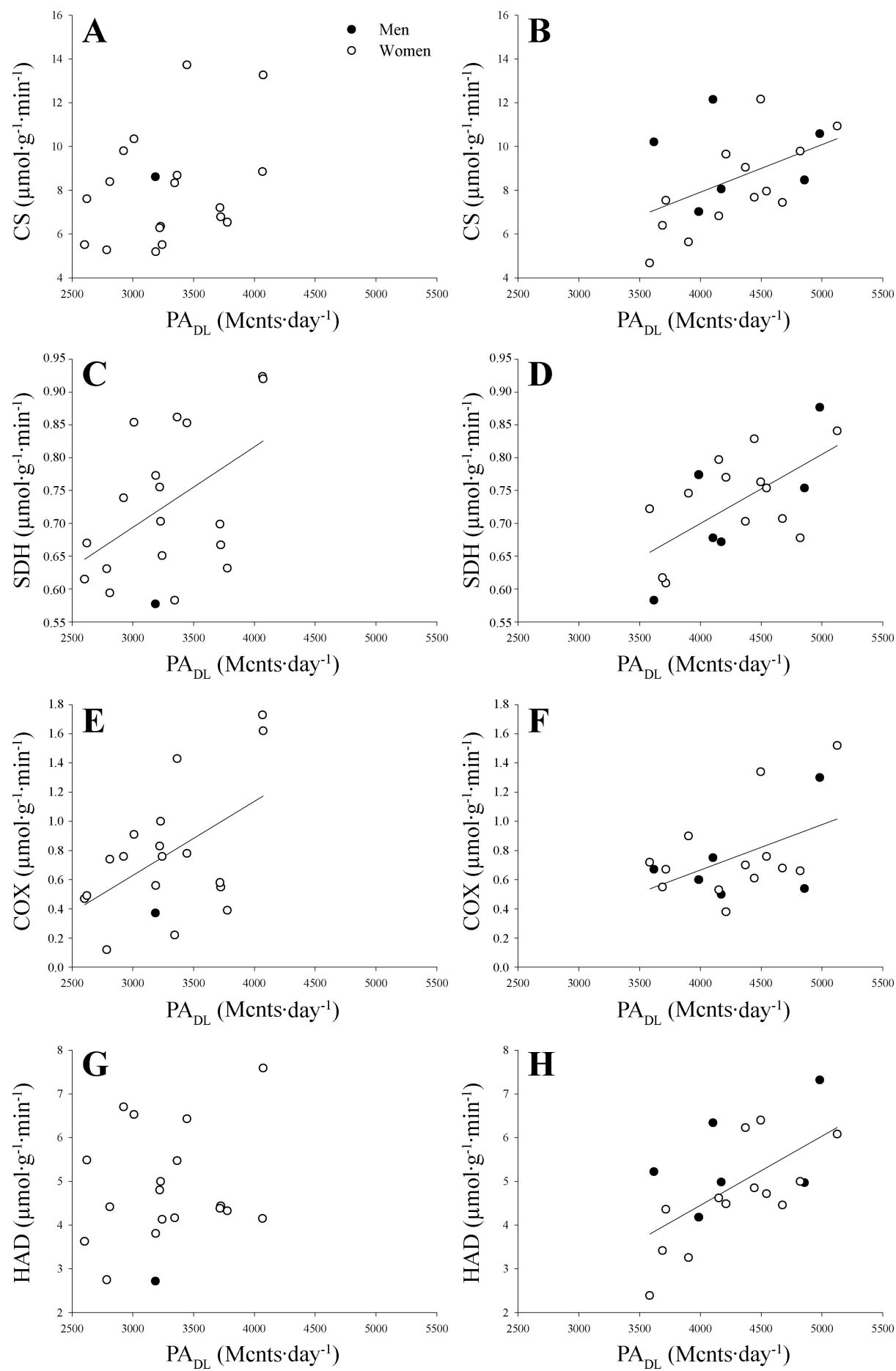

from a decreased time spent on low-intensity physical activity. This implies that the capacity to oxidize fatty acids is positively associated with habitual physical activity in daily life if the latter is accompanied by a decreased time spent on lowintensity physical activity.

For SDH and COX, a positive association with $\mathrm{PA}_{\mathrm{DL}}$ was found both in subjects spending more and less than 39 min on moderate- and high-intensity physical activity per day. Comparable results were obtained within the population stratified based on \%High, suggesting that SDH and COX are associated with habitual physical activity in daily life irrespective of the intensity of the activities performed.

In general, it can be concluded that a sedentary lifestyle does not result in positive associations with mitochondrial capacity, whereas an active lifestyle does. The intensity of the activities performed influences the association with $\mathrm{PA}_{\mathrm{DL}}$ differently for different markers of mitochondrial capacity; it does not appear to affect the association between $\mathrm{SDH}$ and $\mathrm{COX}$ with $\mathrm{PA}_{\mathrm{DL}}$, whereas a limited time spent on low-intensity physical activity appears to be a prerequisite for a positive association between 
$\mathrm{HAD}$ and $\mathrm{PA} \mathrm{DL}_{\mathrm{DL}}$. CS on the other hand only correlated positively with $\mathrm{PA}_{\mathrm{DL}}$ in subjects spending more time on highintensity physical activity. Interestingly though, spending more than $8 \mathrm{~min} / \mathrm{day}$ on high-intensity physical activity already resulted in a positive association between $\mathrm{CS}$ and $\mathrm{PA}_{\mathrm{DL}}$ in healthy young subjects. Whether the positive association between mitochondrial capacity and habitual physical activity in daily life persists in populations at risk for developing Type 2 diabetes and obesity remains to be established. More importantly, it should be examined if spending more than $8 \mathrm{~min} /$ day on high-intensity physical activity accompanied by a high level of habitual physical activity in daily life suffices to maintain or improve proper mitochondrial capacity in populations at risk for developing Type 2 diabetes and obesity. It should be stressed that even if this association holds in populations at risk, no extrapolations to prevention of Type 2 diabetes and obesity can be made. In fact, based on previous studies, $8 \mathrm{~min}$ of high-intensity physical activity per day is unlikely to be sufficient to delay the development of Type 2 diabetes and obesity $(6,19)$.

In conclusion, evidence was found for a positive association between $\mathrm{CS}, \mathrm{SDH}$, and $\mathrm{COX}$ with $\mathrm{PA}_{\mathrm{DL}}$ and a trend toward a positive association between $\mathrm{HAD}$ and $\mathrm{PA} \mathrm{DL}_{\mathrm{DL}}$ irrespective of sex, age, and BMI. With CS and SDH as classic markers for mitochondrial density, mitochondrial capacity was found to be positively associated with $\mathrm{PA}_{\mathrm{DL}}$. Thus, in our population of healthy young adults, an active lifestyle within the range of normal daily life activities is associated with a higher mitochondrial capacity than a sedentary lifestyle and may help to maintain or improve mitochondrial capacity.

\section{ACKNOWLEDGMENTS}

We thank Milou Beelen, Luc van Loon, and René Koopman for their skillful way of obtaining the muscle biopsies. We also thank Loek Wouters for analyzing the deuterium samples.

\section{GRANTS}

This study was funded by Maastricht University.

\section{REFERENCES}

1. Ainsworth BE, Haskell WL, Whitt MC, Irwin ML, Swartz AM, Strath SJ, O'Brien WL, Bassett DR Jr, Schmitz KH, Emplaincourt PO, Jacobs DR Jr, Leon AS. Compendium of physical activities: an update of activity codes and MET intensities. Med Sci Sports Exerc 32: S498-S504, 2000.

2. Befroy DE, Petersen KF, Dufour S, Mason GF, de Graaf RA, Rothman DL, Shulman GI. Impaired mitochondrial substrate oxidation in muscle of insulin-resistant offspring of type 2 diabetic patients. Diabetes 56: 1376-1381, 2007.

3. Bergstrom J. Percutaneous needle biopsy of skeletal muscle in physiological and clinical research. Scand J Clin Lab Invest 35: 609-616, 1975.

4. Black AE, Coward WA, Cole TJ, Prentice AM. Human energy expenditure in affluent societies: an analysis of 574 doubly-labelled water measurements. Eur J Clin Nutr 50: 72-92, 1996.

5. Bouten CV, Verboeket-van de Venne WP, Westerterp KR, Verduin M, Janssen JD. Daily physical activity assessment: comparison between movement registration and doubly labeled water. J Appl Physiol 81: 1019-1026, 1996

6. Brooks GA, Butte NF, Rand WM, Flatt JP, Caballero B. Chronicle of the Institute of Medicine physical activity recommendation: how a physical activity recommendation came to be among dietary recommendations. Am J Clin Nutr 79: 921S-930S, 2004.

7. Dinger MK, Behrens TK. Accelerometer-determined physical activity of free-living college students. Med Sci Sports Exerc 38: 774-779, 2006.

8. Faxen K, Gilderson G, Adelroth P, Brzezinski P. A mechanistic principle for proton pumping by cytochrome $c$ oxidase. Nature 437: 286-289, 2005.
9. Gollnick PD, Armstrong RB, Saltin B, Saubert CW 4th, Sembrowich WL, Shepherd RE. Effect of training on enzyme activity and fiber composition of human skeletal muscle. J Appl Physiol 34: 107-111, 1973.

10. Gollnick PD, Armstrong RB, Saubert CW 4th, Piehl K, Saltin B. Enzyme activity and fiber composition in skeletal muscle of untrained and trained men. J Appl Physiol 33: 312-319, 1972.

11. Gosker HR, Hesselink MK, Duimel H, Ward KA, Schols AM. Reduced mitochondrial density in the vastus lateralis muscle of patients with COPD. Eur Respir J 2007.

12. Hansen AK, Fischer CP, Plomgaard P, Andersen JL, Saltin B, Pedersen BK. Skeletal muscle adaptation: training twice every second day vs. training once daily. J Appl Physiol 98: 93-99, 2005.

13. Hu G, Qiao Q, Silventoinen K, Eriksson JG, Jousilahti P, Lindstrom J, Valle TT, Nissinen A, Tuomilehto J. Occupational, commuting, and leisure-time physical activity in relation to risk for Type 2 diabetes in middle-aged Finnish men and women. Diabetologia 46: 322-329, 2003.

14. Jaworowski A, Porter MM, Holmback AM, Downham D, Lexell J. Enzyme activities in the tibialis anterior muscle of young moderately active men and women: relationship with body composition, muscle cross-sectional area and fibre type composition. Acta Physiol Scand 176: 215-225, 2002.

15. Jebb SA, Moore MS. Contribution of a sedentary lifestyle and inactivity to the etiology of overweight and obesity: current evidence and research issues. Med Sci Sports Exerc 31: S534-541, 1999.

16. Kelley DE, He J, Menshikova EV, Ritov VB. Dysfunction of mitochondria in human skeletal muscle in type 2 diabetes. Diabetes 51: 2944-2950, 2002.

17. Kriska AM, Saremi A, Hanson RL, Bennett PH, Kobes S, Williams DE, Knowler WC. Physical activity, obesity, and the incidence of type 2 diabetes in a high-risk population. Am J Epidemiol 158: 669-675, 2003.

18. Kuczmarski RJ, Flegal KM, Campbell SM, Johnson CL. Increasing prevalence of overweight among US adults. The National Health and Nutrition Examination Surveys, 1960 to 1991. JAMA 272: 205-211, 1994.

19. Laaksonen DE, Lindstrom J, Lakka TA, Eriksson JG, Niskanen L, Wikstrom K, Aunola S, Keinanen-Kiukaanniemi S, Laakso M, Valle TT, Ilanne-Parikka P, Louheranta A, Hamalainen H, Rastas M, Salminen V, Cepaitis Z, Hakumaki M, Kaikkonen H, Harkonen P, Sundvall J, Tuomilehto J, Uusitupa M. Physical activity in the prevention of type 2 diabetes: the Finnish diabetes prevention study. Diabetes 54: $158-165,2005$.

20. McClain JJ, Sisson SB, Tudor-Locke C. Actigraph accelerometer interinstrument reliability during free-living in adults. Med Sci Sports Exerc 39: 1509-1514, 2007.

21. Menshikova EV, Ritov VB, Ferrell RE, Azuma K, Goodpaster BH, Kelley DE. Characteristics of skeletal muscle mitochondrial biogenesis induced by moderate-intensity exercise and weight loss in obesity. $J$ Appl Physiol 103: 21-27, 2007.

22. Mogensen M, Sahlin K, Fernstrom M, Glintborg D, Vind BF, BeckNielsen H, Hojlund K. Mitochondrial respiration is decreased in skeletal muscle of patients with type 2 diabetes. Diabetes 56: 1592-1599, 2007.

23. Plasqui G, Joosen AM, Kester AD, Goris AH, Westerterp KR. Measuring free-living energy expenditure and physical activity with triaxial accelerometry. Obes Res 13: 1363-1369, 2005.

24. Santoro C, Cosmas A, Forman D, Morghan A, Bairos L, Levesque S, Roubenoff R, Hennessey J, Lamont L, Manfredi T. Exercise training alters skeletal muscle mitochondrial morphometry in heart failure patients. J Cardiovasc Risk 9: 377-381, 2002.

25. Seidell JC. Dietary fat and obesity: an epidemiologic perspective. Am J Clin Nutr 67: 546S-550S, 1998.

26. Simoneau JA, Bouchard C. Human variation in skeletal muscle fibertype proportion and enzyme activities. Am J Physiol Endocrinol Metab 257: E567-E572, 1989.

27. Siri WE. Body composition from fluid spaces and density: analysis of methods. 1961. Nutrition 9: 480-491; discussion 480, 492, 1993.

28. Stryer L. Biochemistry. New York: Freeman, 1999.

29. Tarnopolsky MA, Rennie CD, Robertshaw HA, Fedak-Tarnopolsky SN, Devries MC, Hamadeh MJ. Influence of endurance exercise training and sex on intramyocellular lipid and mitochondrial ultrastructure, substrate use, and mitochondrial enzyme activity. Am J Physiol Regul Integr Comp Physiol 292: R1271-R1278, 2007.

30. Toledo FG, Menshikova EV, Ritov VB, Azuma K, Radikova Z, DeLany J, Kelley DE. Effects of physical activity and weight loss on skeletal muscle mitochondria and relationship with glucose control in type 2 diabetes. Diabetes 56: 2142-2147, 2007. 
31. Westerterp KR. Pattern and intensity of physical activity. Nature 410: 539, 2001.

32. Westerterp KR, Meijer GA, Janssen EM, Saris WH, Ten Hoor F. Long-term effect of physical activity on energy balance and body composition. Br J Nutr 68: 21-30, 1992.

33. Westerterp KR, Saris WH, van Es M, ten Hoor F. Use of the doubly labeled water technique in humans during heavy sustained exercise. $J$ Appl Physiol 61: 2162-2167, 1986.
34. Westerterp KR, Wouters L, van Marken Lichtenbelt WD. The Maastricht protocol for the measurement of body composition and energy expenditure with labeled water. Obes Res 3, Suppl 1: 49-57, 1995.

35. Yoshioka M, Ayabe M, Yahiro T, Higuchi H, Higaki Y, St-Amand J, Miyazaki H, Yoshitake Y, Shindo M, Tanaka H. Long-period accelerometer monitoring shows the role of physical activity in overweight and obesity. Int J Obes (Lond) 29: 502-508, 2005.

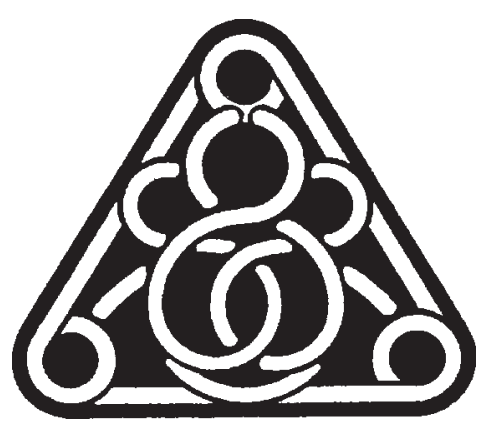

